\title{
Analisis Faktor Yang Mempengaruhi Tumbuhnya Minat Belajar Siswa Di SD Islam Athirah Makassar Kelas 4
}

\author{
Andi Fatmayanti ${ }^{1}$, Tri Susantri ${ }^{2}$ \\ ${ }^{1,2}$ Program Studi Pendidikan Ekonomi, STKIP Pembangunan Indonesia \\ cadandagirl@ymail.com
}

\begin{abstract}
ABSTRAK
Penelitian ini bertujuan untuk mengetahui faktor yang mempengaruhi tumbuhnya minat belajar siswa di SD Islam Athirah Makassar kelas 4.1. Penelitian ini menggunakan pendekatan kuantitatif dengan metode survei deskriptif.Populasi penelitian adalah keseluruhan siswa kelas 4 SD Islam Athirah Baruga Makassar berjumlah 74 orang siswa yang terdiri dari empat kelas, penarikan sampel menggunakan teknik Simple Random Sampling, sehingga terpilih kelas 4.1 sebagai sampel yang berjumlah 20 orang siswa. Data dianalisis menggunakan teknik analisis data statistik yang terdiri dari tahap penyuntingan, input data, dan tahap tabulasi,selanjutnya dipersentasekan kemudian disajikan dalam bentuk tabel dan dijabarkan secara deskriptif. Hasil penelitian menunjukkan persentase metode pembelajaran $14,41 \%$, letak geografis sekolah $(12,56 \%)$, indikator fisik $(11,78 \%)$, model pembelajaran $(11,74 \%)$, bakat $(9,18 \%)$, model pembelajaran $(8,54 \%)$, indikator kebutuhan $(6,28 \%)$, kompetensi sosial (5,97\%), indikator bangunan (5,77\%), kompetensi kepribadian $(5,43 \%)$, dan kompetensi pedagogik (5,30\%).Disimpulkan bahwa, metode pembelajaran adalah faktor yang paling berpengaruh terhadap tumbuhnya minat belajar siswa di SD Islam Athirah Makassar kelas 4.
\end{abstract}

Kata kunci: Minat belajar

\section{ABSTRACT}

This research aims to determine the factors that influence the growing interest in learning of students in Athira Makassar Islamic Elementary school in class 4.1. This study uses a quantitative approach with descriptive survey method. The population of the research was 74 fourth grade students of Athira Makassar Islamic Elementary school, consist of 4 classes, the sampling using simple random sampling technique, so that class 4.1 was chosen as a sample of 20 students. Data were analyzed using statistical data analysis technique which consisted of editing, data tabulated stages, then presented and then presented in table form and described descriptively. The result showed a percentage of learning method $14,41 \%$, the geographical location of the school 12,56\%, phisycal indikator 11,78\%, learning models $11,74 \%$, talent $9,18 \%$, learning models $8,54 \%$, indikator of needs $6,28 \%$, social competence 5,97\%, building indikator $5,77 \%$, personality competence 5,43\%, and pedagogic competence 5,30\%. It was concluded that the learning method was the most influential factor in the growth of student's interest in learning at Athira Makassar Islamic Elementary school grade 4.

Keywords: Learning interest

\section{\begin{tabular}{lll}
\multicolumn{3}{c}{ PENDAHULUAN } \\
Erikson dalam Upton (2012)
\end{tabular}} mengemukakan bahwa anak usia sekolah yang berada pada kisaran usia 6 hingga 11 tahun memiliki tugas perkembangan dalam hal mengatasi tuntutan-tuntutan sosial dan akademik baru. Keberhasilan akan memunculkan rasa berkemampuan, sedangkan kegagalan memunculkan inferioritas. Dalam proses pembelajaran, siswa akan merasa lebih percaya diri jika memiliki prestasi atau hasil belajar yang baik dan sebaliknya akan merasa rendah diri jika memiliki hasil belajar atau prestasi yang tidak baik atau rendah. Tinggi rendahnya hasil belajar ataupun prestasi yang diperoleh siswa dipengaruhi oleh banyak faktor, salah satunya adalah minat belajar. Penelitian yang dilakukan oleh Dinar dan Gatot (2015) yang berjudul Pengaruh Minat dan Motivasi terhadap Hasil Belajar pada Mata 
Pelajaran Pengantar Administrasi Perkantoran menunjukkan pentingnya minat belajar bagi siswa, hal ini dikarenakan hasil penelitian menunjukkan motivasi tidak memiliki pengaruh yang signifikan terhadap hasil belajar namun sebaliknya minat dianggap sebagai variabel yang dominan yang mempengaruhi hasil belajar, dikemukakan juga oleh Sagala (2008), terdapat beberapa syarat agar peserta didik berhasil belajar diantaranya peserta didik harus menimbulkan minat yang tinggi terhadap mata pelajaran (interest inventory) dan mengembangkan potensi sesuai dengan bakat dan minat yang dimiliki.

Makmun (2009: 165) menggambarkan komponen-komponen dalam Proses Belajar Mengajar (PBM), meliputi: karakter siswa sebagai raw input, instrumental input (sarana), environmental input (lingkungan) serta the expected output atau hasil belajar yang diharapkan yang dapat dilihat dari beberapa aspek yaitu, perilaku kognitif, perilaku afektif dan perilaku psikomotor.

Instrumental input (sarana):

1. guru

2. metode

3. media

Raw input:

1. Kapasitas (IQ)

2. Bakat khusus

3. Motivasi n-Ach

4. Minat

5. Kematangan/ kesiapan

6. Sikap/ kebiasaan

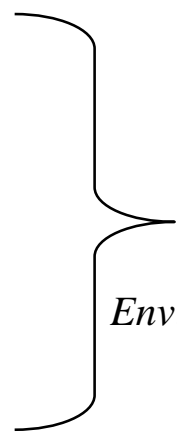

4. bahan/ sumber

5. program tugas

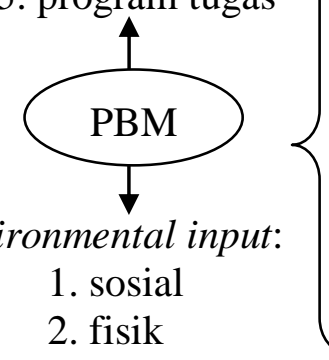

Expected output

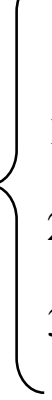

1. Perilaku kognitif

2. Perilaku afekif

3. Perilaku psikomotor

3. kultural

Skema 1. Komponen-Komponen dalam Proses Belajar Mengajar (PBM)

Berdasarkan skema di atas, terdapat beberapa raw input yang mempengaruhi hasil belajar, diantaranya minat belajar siswa. Penelitian ini mengkaji faktor yang berpengaruh terhadap minat belajar siswa kelas 4 SD Islam Athirah Makassar, ini dikarenakan tidak semua siswa memiliki minat belajar. Minat belajar dapat ditandai dengan tingkat perhatian yang tinggi terhadap pembelajaran dan adanya ketertarikan untuk belajar. Ahmadi \& Supriyono (2013) berpendapat bahwa ada tidaknya minat terhadap sesuatu pelajaran dapat dilihat dari beberapa hal diantaranya cara anak mengikuti pelajaran dan kelengkapan catatan.

\begin{tabular}{ccc}
\multicolumn{2}{c}{ METODE PENELITIAN } \\
Penelitian ini menggunakan
\end{tabular} pendekatan kuantitatif dengan jenis penelitian survei deskriptif. Populasi penelitian adalah keseluruhan siswa kelas 4 SD Islam Athirah Baruga Makassar yang berjumlah 74 orang siswa yang terdiri dari empat kelas. Penarikan sampel menggunakan teknik Simple Random Sampling, sehingga terpilih kelas 4.1 sebagai sampel penelitian dengan jumlah siswa sebanyak 20 orang.

Teknik pengumpulan data yang digunakan dalam penelitian ini ada dua yaitu. Pertama, kuesioner, dalam hal mengelola kuesioner kepada sampel responden, peneliti menerapkan cara selfadministered questionnaires yaitu responden mengisi sendiri kuesioner disertai pengawasan, yang sebelumnya diuji cobakan terebih dahulu. Kuesioner dalam penelitian ini menggunakan pernyataan tertutup dengan prosedur pengukuran skala likert yang merupakan format dimana responden diminta memilih apakah sangat setuju, setuju, netral, tidak setuju dan sangat tidak setuju terhadap suatu pernyataan yang meminta persetujuan resonden. (Morissan: 2015). Berikut ini adalah format pemberian skor 
dengan menggunakan prosedur pengukuran skala likert:

$\begin{array}{ll}\text { sangat setuju } & : 5 \\ \text { setuju } & : 4 \\ \text { netral } & : 3 \\ \text { tidak setuju } & : 2 \\ \text { sangat tidak setuju } & : 1\end{array}$

Intrumen yang kedua adalah wawancara. Wawancara yang digunakan adalah wawancara yang tidak terstruktur yang diperuntukkan untuk guru BK yang bertujuan untuk memperoleh data mengenai jumlah siswa yang akan dijadikan populasi dan sampel.

Teknik analisis data yang digunakan dalam penelitian ini adalah teknik analisis data statistik, yang terdiri atas beberapa tahap. Pertama, penyuntingan, tahap penyuntingan dilakukan untuk memastikan kelengkapan dalam hal pengisian kuesioner oleh siswa. Kedua, input data, dalam tahap ini peneliti mulai melakukan pengklasifikasian berdasarkan sejumlah kategori pilihan jawaban kuesioner yang tersedia. Ketiga, tabulasi, pada tahap ini data yang telah diinput kemudian dihitung frekuensinya. Setelah itu data dipersentasekan dengan menggunakan rumus:

$$
P=\frac{f}{n} \times 100 \%
$$

Keterangan :

P: Persentase

f: Frekuensi jawaban

n: Jumlah total jawaban/ skor
Keempat, data yang telah dipersentasekan tersebut kemudian disajikan dalam bentuk tabel, yang selanjutnya dijabarkan secara deskriptif.

\section{HASIL \& PEMBAHASAN}

\section{Hasil Uji Coba Kuesioner}

Instrumen penelitian ini adalah kuesioner yang terlebih dahulu dibuatkan kisi-kisi, sehingga terdapat beberapa indikator yang terkait dengan minat belajar. Sebelum dibagikan kepada siswa yang menjadi sampel peneltian, kuesioner diuji coba terlebih dahulu. Uji coba dilakukan untuk memastikan tingkat validitas sebuah instrumen. Berdasarkan hasil uji validitas, diperoleh 34 item pernyatan yang valid dan akan dijadikan sebagai item pernyataan dalamkuesioner penelitian.

Setelah tahap uji coba, kuesioner kemudian disebarkan kepada 20 orang siswa yang menjadi sampel penelitian sebagai instrumen yang digunakan untuk mengetahui faktor yang mempengaruhi tumbuhnya minat belajar siswa di SD Islam Athirah Makassar kelas 4.1.

\section{Faktor yang Mempengaruhi Tumbuhnya Minat Belajar Siswa}

Minat belajar merupakan dorongan untuk belajar yang dipengaruhi oleh ketertarikan yang tinggi, sebagaimana menurut Syah (2013: 152) bahwa, minat (interest) berarti kecenderungan dan kegairahan yang tinggi atau keinginan yang besar terhadap sesuatu. Aspek internal dan eksternal siswa menjadi faktor yang mempengaruhinya, berdasarkan hasil analisis kuesioner diperoleh data sebagai berikut:

Tabel 1 Distribusi Frekuensi Setiap Indikator Penelitian

\begin{tabular}{|c|c|c|c|}
\hline No & Indikator & Skor (f) & Persentase (\%) \\
\hline 1 & Bakat & 269 & 9,18 \\
\hline 2 & Kebutuhan & 184 & 6,28 \\
\hline 3 & Fisik & 345 & 11,78 \\
\hline 4 & Media Pembelajaran & 250 & 8,54 \\
\hline 5 & Metode Pembelajaran & 422 & 14,41 \\
\hline 6 & Model Pembelajaran & 344 & 11,74 \\
\hline 7 & Kompetensi Profesional & 89 & 3,04 \\
\hline 8 & Kompetensi Pedagogik & 155 & 5,30 \\
\hline 9 & Kompetensi Kepribadian & 159 & 5,43 \\
\hline 10 & Kompetensi Sosial & 175 & 5,97 \\
\hline 11 & Bangunan & 169 & 5,77 \\
\hline \multirow[t]{2}{*}{12} & Letak Geografis Sekolah & 368 & 12,56 \\
\hline & & 2929 & $100 \%$ \\
\hline
\end{tabular}


Berdasarkan tabel di atas diperoleh hasil penelitian bahwa, metode pembelajaran memiliki tingkat persentase tertinggi sebagai faktor yang mempengaruhi tumbuhnya minat belajar siswa di SD Islam Athirah Makassar kelas 4.1, yaitu sebesar $14,41 \%$. Metode mengajar merupakan cara yang dipergunakan guru dalam melaksanakan pembelajaran, sebagaimana menurut Ghunaimah

dalam Ramayulis (2015:264) bahwa, metode adalah cara-cara yang praktis dalam mencapai tujuan pengajaran.

Urutan kedua ditempati oleh letak geografis sekolah dengan persentase $12,56 \%$. Letak geografis sekolah dalam penelitian ini adalah situasi, dan letak sekolah yang dapat menjadi faktor penunjang atau penghambat tumbuhnya minat belajar siswa, yang dimana menurut makmun (2009: 166) termasuk dalam komponen environmental input.

Ketiga, adalah indikator fisik dengan persentase $11,78 \%$. Indikator fisik dalam penelitian ini diartikan sebagai kondisi jasmani siswa yang menandai tingkat kebugaran organorgan tubuh dan sendi-sendinya, yang dapat berpengaruh terhadap semangat dan intensitas siswa dalam mengikuti pelajaran, sebagaimana dijelaskan sebelumnya bahwa, minat belajar dapat terlihat dari tingkat perhatian siswa dalam mengikuti pembelajaran.

Keempat, model pembelajaran, dengan persentase $11,74 \%$. Model pembelajaran dalam penelitian ini merujuk pada pendapat Joyce \& Weil dalam Rusman (2014: 133) yaitu suatu rencana atau pola yang dapat digunakan untuk membentuk kurikulum (rencana pembelajaran jangka panjang), merancang bahan-bahan pelajaran, dan membimbing pembelajaran di kelas.

Kelima adalah bakat dengan persentase 9,18\%. Chaplin dan Reber dalam Syah (2013: 151) menjelaskan bahwa, bakat (aptitude) adalah kemampuan potensial yang dimiliki seseorang untuk mencapai keberhasilan pada masa yang akan datang. Dijelaskan pula bahwa bakat merupakan kemampuan individu untuk melakukan tugas tertentu tanpa banyak bergantung pada upaya pendidikan dan latihan.

Keenam, media pembelajaran, dengan persentase $8,54 \%$. Ibrahim dan Syaodih dalam Rusman (2014: 77) menjelaskan bahwa media adalah segala sesuatu yang dapat digunakan untuk menyampaikan materi serta mampu merangsang pikiran, perasaan, perhatian dan kemampuan siswa. Dijelaskan pula, bahwa kemampuan guru dalam menggunakan media dapat terlihat tidak hanya dari kemampuannya dalam menggunakan media yang telah tersedia namun kemampuannya memanfaatkan objek nyata yang ada di lingkungan termasuk di sekitar sekolah.

Ketujuh, indikator kebutuhan, 6,28\%. Indikator kebutuhan dalam penelitian ini dimaksudkan untuk melihat sejauhmana indikator ini berpengaruh terhadap minat belar siswa sebagaimana Makmun (2009: 163) mengemukakan bentuk proses belajar whatwhy-how? Yang di dalamnya terdapat tahapan felt needs, drive, yaitu tahapan dimana siswa belajar karena merupakan kebutuhan. Misalnya, ingin meningkatkan atau mempertahankan prestasinya (competition).

Kedelapan, kompetensi sosial, dengan persentase $5,97 \%$. Kompetensi sosial menunjukkan kemampuan berkomunikasi dan berinteraksi secara efektif, baik dengan muridnya, sesama guru, atasan dan masyarakat.

Kesembilan, indikator bangunan dengan persentase $5,77 \%$. Indikator bangunan dalam penelitian ini adalah kondisi fisik sekolahdimana tersedia tidaknya tempat atau ruangan yang memadai yang meliputi, besarnya ruangan, tata letak, dan ventilasi.

Kesepuluh, kompetensi kepribadian, dengan persentase 5,43\%. Kompetensi kepribadian guru menggambarkan guru sebagai sosok dengan kepribadian yang mantap, stabil, dewasa, arif dan berwibawa, dimana kepribadiannya tersebut dapat dijadikan teladan atau contoh bagi peserta didiknya.

Kesebelas, kompetensi pedagogik, dengan persentase 5,30\%.Kompetensi ini berkaitan dengan perencanaan, dan pengelolaan pembelajaran. Meliputi kemampuan dalam membuat perangkat pembelajaran, melaksankaan pembelajaran, dan mengevaluasi hasil pembelajaran.

Keduabelas, kompetensi profesional, dengan persentase $3,04 \%$. Kompetensi profesional guru merujuk pada tingkat penguasaan materi pembelajaran yang sesuai dengan Standar Nasional Pendidikan sebagaimana penjelasan Pasal 28 ayat 3 butir c dalam Rusman (2014: 23) bahwa, guru harus memiliki pengetahuan yang luas berkenaan dengan bidang studi yang akan diajarkan serta penguasaan didaktik metodik dalam arti memiliki pengetahuan konsep teoritis, mampu memilih model, strategi, dan metode yang tepat serta mampu menerapkannya dalam kegiatan pembelajaran. 


\section{KESIMPULAN \& SARAN}

Berdasarkan hasil penelitian, disimpulkan bahwa metode pembelajaran adalah faktor yang paling berpengaruh terhadap tumbuhnya minat belajar siswa di SD Islam Athirah Makassar kelas 4.1, dengan tingkat persentase sebesar $14,41 \%$. Persentase ini merupakan persentase tertinggi dari persentase keduabelas indikator yang dijadikan sebagai faktor untuk mengukur tumbuhnya minat belajar siswa di SD Islam Athirah Makassar kelas 4.1.

Adapun saran peneliti berdasarkan kesimpulan penelitian ini adalah pentingnya upaya pengembangan diri bagi guru guna merangsang kreativitas dan inovatif dalam menerapkan berbagai metode pembelajaran yang sesuai dengan prinsip kebutuhan peserta didik dan kesesuaian dengan tujuan pembelajaran, sehingga pembelajaran tidak hanya menarik namun juga mampu mengembangkan seluruh potensi peserta didik.

\section{DAFTAR PUSTAKA}

Ahmadi \& Supriyono. 2013.Psikologi Belajar. Jakarta: Rineka Cipta

Dinar \& Gatot. 2015. Pengaruh Minat dan Motivasi terhadap Hasil Belajar pada Mata Pelajaran Pengantar Administrasi Perkantoran. Jurnal Pendidikan Bisnis dan Manajemen. Vol 1, No. 2. (portalgaruda.org, diakses 22 April 2017)

Makmun. 2009. Psikologi Kependidikan. Bandung: Rosdakarya

Morissan: 2015. Metode Penelitian Survei. Jakarta: Kencana Prenada

Ramayulis. 2015. Dasar-Dasar Kependidikan. Jakarta: Kalam Mulia

Rusman. 2014. Model-Model Pembelajaran. Depok: Rajagrafindo

Sagala. 2008. Konsep Dan Makna Pembelajaran. Bandung: Alfabeta

Syah. 2013. Psikologi Belajar. Depok: Rajagrafindo

Upton. 2012. Psikologi Perkembangan. Jakarta: Erlangga 